\section{Victory for women's rights in Kuwait reawakens hope}

\author{
Empowering women is seen as an essential step \\ to improving health and development in \\ the Middle East. Zosia Kmietowicz talks to \\ Lulwa Almulla, who describes herself as one \\ of Kuwait's "first women's activists"
}

For the past 26 years Lulwa Almulla has worked around the world and in her home country to promote the rights of women. She has camped with fellow campaigners outside the tents where male Kuwaiti politicians had gathered, determined to be allowed to take part in the discussions. And she has stood besides thousands of other women in the searing heat and humidity to demonstrate their commitment to voting rights.

Almulla's efforts finally paid off in May last year when Kuwaiti women were granted the right to vote and run for public office.

"I felt victorious that I had played a part in this historic moment. Use whatever words you need to explain that joy," she says.

Although Almulla helps to run the family business in real estate and investments, it is her volunteering work that motivates her. "I have my own office and job. But it [my work with the society and the suffrage movement in Kuwait] is my main interest. It takes all my life. But I love it," she said.

It is a paradox that Kuwait should have been one of the last countries in the Middle East to give women political rights. In many respects the country is one of the most advanced in the Persian Gulf. Kuwaiti women make up $70 \%$ of university students and $40 \%$ of the workforce. Women are present in all professional fields, including education, medicine, and journalism, as well as business and government.

But the work to promote women's rights does not end with winning the vote, says Almulla. The next step is to train women to become elected members of parliament and to take an active role in deciding the country's direction.

Almulla first became politically active at the Beirut College for Women at Kuwait University in 1968. Since 1991 she has been secretary general of the Women's Social and Cultural Society in Kuwait, an organisation set up in 1963 by some of Kuwait's first women university graduates. The society's aim is simple: to encourage women in all fields, from promoting their participation in community activities to increasing their awareness of their political and legal rights.

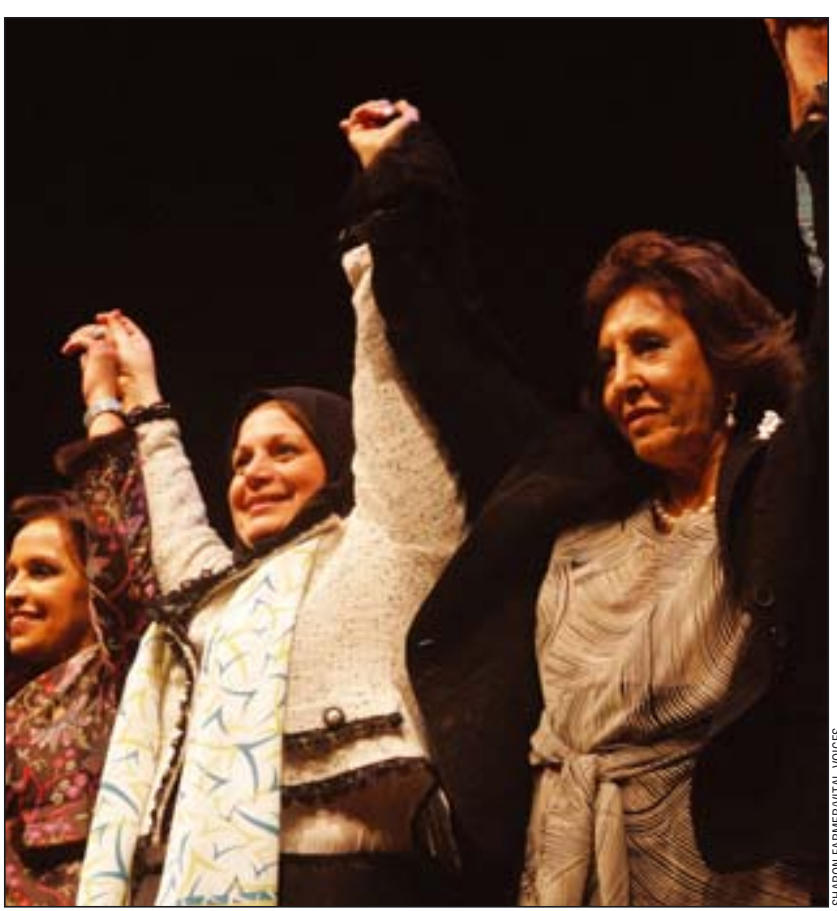

Women in Kuwait win the right to vote: Lulwa Almulla (right) joins the celebrations

It is not unusual for a Kuwaiti woman to get to the position that she has been able to, says Almulla. She was brought up in what she calls "a relatively liberal Kuwaiti family."

Her father was the secretary of the government of Kuwait, a position next filled by her brother and later by her nephew. And her niece, Nabeela Almulla, is Kuwait's first woman ambassador, who represented Kuwait from the Ministry of Social Affairs and Labour and partly through its own fundraising efforts. It runs projects in Kuwait and abroad.

Among its many activities in Kuwait the society has established the Al Amal (which means hope) club to pay for health care and treatment of people without national status, such as Bedouins, and non-Kuwaitis, who are not entitled to health- in the United Nations and is currently ambassador to Belgium.

"The environment I was brought up in was very conducive to building my political and social interests. I also had the opportunity to study in Beirut for two years during my college years, where there existed an extremely vibrant political environment that I became part of," she explains.

The society Almulla heads is funded partly by an annual grant

\section{.} ependence."

Almulla has said that progress made by women in other Middle Eastern countries fuelled her determination and that of other Kuwaiti activists to step up their fight for the right to vote (Washington Post, www. washingtonpost.com, 29 June 2005, "Kuwait's political tent makes room for women"). She has no doubt that promoting women's rights in Kuwait and elsewhere in the Middle East has repercussions throughout the region.

"The victory of the struggle for women's rights in Kuwait is indeed a great achievement and one that gives hope to both Kuwaitis and to the people of the region," she said. "As far as Kuwait is concerned, the gaining of the rights at this time in history has contributed to the reawakening of hope that progress, and more precisely, liberal and democratic progress, is possible, after many years through which the country has sunk into increased religious fanaticism, corruption, and the curtailing of the people's democratic and constitutional rights.

"This hope is naturally extended to other liberal forces in the region. Thus, reaping the fruits of our struggle is a boost to these forces and an encouragement to their struggles, as they see light of progress in a society within their region."

Zosia Kmietowicz London 